\title{
Evaluation of Ilm Ideas Phase I Programme of UK aid for Education in Pakistan
}

\author{
Nauman A. Abdullah*, Dr. Sadaf Jabeen **, Dr.Mahr Muhammad Saeed Akhtar***
}

\begin{abstract}
The role of donor agencies is considered significant in supporting the social development of developing countries, especially the education sector. UK aid also supports the education system of Pakistan to uplift its education indicators and educational outcomes. Ilm ideas programme was one such reform initiative by UK aid for Pakistan with the purpose to improve access to quality education, increase awareness on transparency and accountability, and enhancing the learning of students. This research was undertaken to evaluate this programme using document analysis technique. The evaluation was done with a focus on recipients' perspective as it further compared and analysed the results of the programme with outcomes and indicators of education system of Pakistan. This has given the actual picture of the interventions and their outcomes. The research outcomes have multifold significance for education sector of Pakistan, UK aid, indigenous and international research scholar and critics. Programme evaluation practices might also increase as a result of this research.
\end{abstract}

Keywords: Programme evaluation, document analysis, ilm ideas, voice and accountability, innovative fund for education.

This Article can be cited as:

Abdullah N A., Jabeen S., Akhtar M M S., (2020). Evaluation of Ilm Ideas Phase I Programme of UK aid for Education in Pakistan, Journal of Arts and Social Sciences. VII (2), 101-115.

\footnotetext{
* Correspondence concerning this article should be addressed to Nauman Ahmed Abdullah, Lecturer, Department of Education, Virtual University of Pakistan, nauman101@ @otmail.com.

** Dr. Sadaf Jabeen, Assistant Professor, Lahore College for Women University, Lahore sadaf.jabenl@ @mail.com.

*** Prof. Dr. Mahr Muhammad Saeed Akhtar, Dean (Academics), ISLAAH, Lahore mahrsaeed1@yahoo.com .
} 


\section{Introduction}

International donor organizations have been established to support social development across the world. Education is considered as an imperative social development factor. Foreign aid agencies, whether multi-lateral or bi-lateral, place education on their priority list. They have been supporting education systems throughout the world, especially those of developing countries. Countries that show low performances on the global indicators of education have complex educational issues. Most obvious of them are financial and technical inadequacies. It is another common fact that developed countries have better education systems as compared to developing countries because of more budgetary spending. A few common international indicators for educational rankings and quality are literacy rate, gross and net enrolment rates, global innovation index, and international standardized large scale assessment tests such as Trends in International Mathematics and Science Study (TIMSS) and Programme for International Student Assessment (PISA).

Pakistan has been struggling to show any substantial progress in the educational outcomes be it achieving the targets of Millennium Development Goals (MDGs), low primary enrolment rate of students, out of school children, literacy rate, gender parity, rural-urban balance or global innovation index, and many others. Besides these low performances in global indicators, Pakistan has not participated in TIMSS and PISA, therefore the quality of education and learning capabilities of students is also questionable. This low standard of education in Pakistan may be attributed to low percentage spending of Gross Domestic Product (GDP) on education i.e. 2.1\% (Government of Pakistan, Finance Division, 2017-18), low education development budget allocation and more recurrent expenditures (Government of Pakistan, Ministry of Finance, 2018), over population - a total of 207,774,520 inhabitants as per the latest 2017 population census (Pakistan Bureau of Statistics, 2017), lack of use of ICT, and parallel systems of education for different social class. According to Pakistan Bureau of Statistics (2016) Pakistan Social and Living Standards Measurement (PSLM) reported the adult literacy rate of 57\% only, with a divide of rural-urban of 51-76\% and male-female division of 68-45\%. According to Pakistan Education Statistics (2016-17) there were 22.84 million out of school children in Pakistan. These projections were based on the previous population census of 1998, it is estimated that based on the 2017 population census this number might also increase. Gross enrollment rate of primary level for six to 10 years age was 92\% (Pakistan Bureau of Statistics, 2016). The survival rate to grade five was $67 \%$ in the year 2016-17, and Effective Transition Rate (ETR) was 84\% of primary to middle classes (Pakistan Education Statistics (2016-17).

The education system of Pakistan is running on the foundations as laid by the British, during their rule over the sub-continent (Asim \& Shah, 2014). The system has seen a fair number of policies and plans since then (Academy of Educational Planning and Management, 2018) but after several policies and plans the education indicators are yet below standard (Bengali, 1999). As a result, many foreign aid organizations tend to support the education system of Pakistan through various aid programmes and interventions. UK aid has historically aided the most in education sector of Pakistan (DFID Operational Plan, 2014). Its Department for International Development (DFID) is a formal aid agency that invests part of its GDP to support the social development in developing countries. DFID - a bi-lateral organization has initiated many long term multi-level programmes for the education sector of Pakistan (DFID Projects in Pakistan, 2016). All these support programmes are marked, approved, initiated and executed through government channels. Both UK and Pakistan governments are involved in these programmes. A programme 'Ilm Ideas (learning ideas)' was specially initiated to enhance the access to quality education to school age children and raise awareness in the general public about transparency and accountability in the education system and to make innovative solutions for enhancing learning. In this programme, UK aid had initiated two main funds (1) voice and accountability fund (2) innovative fund for education. These were long term funds with separate objectives and intended outcomes. The duration of these funds has been completed and now this programme is in post-completion stage. 
Programme evaluation is pertinent research type in aid phenomenon (Chen, 2005). There are a few worth mentioning studies that deal with aid evaluation and programme evaluation such as (Sarwar, Hassan \& Mahmood, 2015; Steiner-Khamsi, 2006). Especially evaluating the UK aid phenomenon and aid programmes, Robertson (2005) gives a comprehensive background and policy analysis. Third party evaluation is highly recommended in such cases. Although the foreign aid agencies in general and DFID in particular emphasize rigorously on continuous monitoring and evaluation, yet an independent analysis from the perspective of the recipients is direly needed to see the impact of UK aid in terms of educational outcomes. The programme 'ilm ideas' focused on addressing the crucial issues that the education system of Pakistan is confronted with. Many interventions have been initiated during the stipulated time frame of this programme. Now that the programme has completed and the interventions have taken time to yield their outcomes and impact, it is high time to evaluate this programme. Therefore, this research was undertaken to evaluate the programme ilm ideas by assessing both funds 'voice and accountability' and 'innovative fund for education'. This programme evaluation is significant as its outcome may help in analyzing its impact. It might be useful to the education system of Pakistan specially school education department where all its interventions were largely focused. It may be of interest to UK aid to evaluate its funds and interventions from a third party review with the recipients' perspective addition. Further, gaps are identified as an outcome of this review and document analysis that might be useful for policy makers and other researchers to study further.

\section{Main Question of the Research}

The main question of this research was to find the benefits of the ilm ideas programme in terms of the change it has brought to the education indicators of Pakistan.

\section{Subsidiary questions}

1. What were the objectives of the two funds voice and accountability and innovative fund for education?

2. What interventions were introduced to achieve those objectives?

3. How far were those objectives met?

4. What changes in the educational outcomes ilm ideas programme has brought?

\section{Methodology}

Programme evaluation research type was used to evaluate the ilm ideas programme. Qualitatively a document analysis was conducted that included a critical review of the UK aid annual reviews, progress, and targets achieved against each planned indicator of the UK aid. Document analysis is a systematical and planned analysis of the documents against pre-set criteria to achieve the objectives of the research (Bowen, 2009). This analysis is carried out qualitatively (Yin, 2011) to dig into the data in order to have a deep insight and understanding of different aspects related to the data (Yin, 2009). This study opted document analysis in two-stages, earlier the official documents of UK aid were reviewed and at second stage the findings from that analysis were compared with the educational ground realities and indicators of education sector of Pakistan, published in various public reports. For that purpose, an analytical review of all formal and official educational reports and indicators of Pakistan was carried out.

\section{Procedure}

The criteria to do the document analysis- in compliance with the ethical considerations of this study- were as follows: selection of documents that align with the objective of the research (Padilla-Diaz, 2015); the documents should be official, formal and public; all annual reviews reported for DFID on both funds, review the whole documents repeatedly and pick only relevant information that is congruent with 
the objectives (Corbin \& Strauss, 2008); review the selected information and identify possible answers for the research questions (Braun \& Clarke, 2006); repeat the analysis until saturation point comes (Angers \& Machtmes, 2005); once the saturation point - no further information is left unidentified - comes write a draft of answers for all research questions.

After analyzing the annual reviews and other documents of the UK aid, the second stage of document analysis was to compare the findings from that analysis with the review of educational reports and education indicators. For this second analysis, following criteria were followed: selection of governmental educational reports; analyzing the educational outcomes from the reports; comparing the education indicators and educational outcomes with findings of document analysis of stage 1 . The documents analyzed during document analysis of education voice and accountability fund and innovative fund for education, separately, were: Annual review 1, annual review 2, annual review 3, project completion review, and logical framework. For comparison and analytical review in stage two, the documents analyzed were: Pakistan Education Statistics reports of 2017, 2016, 2015, ...2011, Pakistan Bureau of Statistics reports of 2017, 2016, 2015,..2011, Federal and provincial budgets from 2018 till 2011, Annual Status of Education Report (ASER) for the years 2015 to 2011, district education rankings and reports of school education department and its affiliated departments such as PMIU, DSD/QAED, PEC, PEF, NEAS and PITB.

\section{Ilm Ideas Programme}

The umbrella programme initiated by UK aid had two significant funds. The two funds as explained below had specific objectives; therefore, the document analysis has been done separately for them.

\section{Voice and Accountability Fund}

This initiative lasted over four years starting from November 15, 2011 to ending on October 31, 2015. This four year fund had a budget of 5 million pounds. This programme was reviewed annually by a third party. That review comprehensively covered all the aspects of this fund. The review analyzed financial release of funds, activities performed throughout the year, challenges faced during the course of action, and has given recommendations on what to do and how to do in coming years. Therefore, the researcher has analyzed the documents in a specialized way to find out the answers that were specific to the research questions only.

\section{Who are the recipients of UK aid-V\&A Fund}

DFID does not directly fund in any country. They have their partners who they call as fund managers. In this V\&A fund which was working under the ambit of ilm ideas programme, the funding and technical assistance body partnering with DFID was Development Alternatives International (DAI). It is a global development company that delivers social and economic development in countries across the globe. They work with multi-lateral organizations, bi-lateral organizations and private sector. DFID had released funds to them and DAI had funded the different projects falling under this programme. Through DAI the fund was distributed to other grantees as well. The details of those recipients-mainly Civil Services Organizations (CSOs), Non-Governmental Organizations (NGOs), International Non-Governmental Organizations (INGOs), and media institutions - have been discussed in the interventions section.

\section{How are the recipients selected?}

After the international partner who would spend and allocate UK aid funds, the next step in answering this question is how that international body further selects the local bodies/ agencies to spend the funds in different projects. For that purpose, Requests for Application (RFA) is opened and proposals are received. 
For those proposals application forms were introduced to yield applications that could be funded. The process of selecting the applications is also rigorous. Through their value for money (VFM) consideration, they ensured economy, efficiency and effectiveness of the funds. Grant applications were vetted by means of:

1. Administrative review

2. Technical review

3. Due diligence visit

\section{What specific interventions are introduced by UK aid?}

Every programme has specific interventions and that are based on the purpose of the fund, its scope and the goals that are set for the programme duration. To understand the interventions one needs to realize the purpose and intended outcomes of each programme, first. Therefore, the purpose and planned goals are discussed before highlighting the specific interventions.

\section{Purpose of the fund}

The purpose of this fund was to nurture the public demand for better quality education services by contributing to provide universal access to quality education for children 5-16 years old by making the education system more transparent and accountable to the public. These were the outcome targets for Education Voice and Accountability to be achieved by 2015.

1. Twelve policy decisions made and communicated to the public by decision-makers, ensuring transparency and accountability;

2. A four percent increase in budgets targeting education disaggregated by province and districts;

3. Four hundred schools with improved governance (transparency and accountability) as a result of V\&A fund activities.

In order to meet these outcomes, there were some intended outputs to be achieved by 2015 and every output had certain specific targets. This mechanism goes bottom up-if all targets for an output are reached, then that output is accomplished and if all the four outputs are achieved then the overall outcomes are realized.

\section{Expected outputs}

There were four outputs of this fund.

1. Increased availability of evidence based knowledge (information and analysis, including gender analysis) on education systems.

2. Increased public access to education related information through TV talk shows, public sector announcements, advertisements, radio programming, social media/ websites.

3. Strengthened and coordinated community action on education.

4. Improved responsiveness of policymakers towards basic education services.

These four outputs had different targets and through attainment of those targets this voice and accountability fund was evaluated. On annual basis a detailed review report was published in which the evaluation of each target was done. Every year the targets were increased or re-set in order to achieve the outcomes.

In order to achieve these targets different grantees were selected or what they call nine publications since these three targets will yield nine separate research reports. Two projects or grantees were involved 
LEAD Pakistan- Public oversight and transparency of School Councils and Consumer Right Commission of Pakistan (CRCP). LEAD Pakistan worked for two districts of Sindh and CRCP has worked in Punjab.

The initiatives taken under V\&A fund were throughout Pakistan segregated into four provinces: Punjab, Sindh, Baluchistan, Khyber Pakhtunkhwa, and Gilgit Baltistan, and Azad Jammu and Kashmir $(\mathrm{AJK})$ as well. There were 23 organizations involved in this V \& A fund with 25 fund grants. The name of these 23 organizations are as follows: Indus Resource Centre (IRC), Consumer Right Commission of Pakistan (CRCP), Century publications, Institute of Social and Policy Sciences (I-SAPS) Special, SAQE, Civil Society Support Programme (CSSP), Farmers Development Organization (FDO), LEAD, Democratic Commission for Human Development (DCHD), Mishal, Trust for Democratic Education/Free And Fair Election Network (TDEA-FAFEN), Centre for Governance and Public Accountability (CGPA), SDPI, Women's Welfare Organization Poonch (WWOP), Society for the Protection of Rights of Child (SPARC), Center for Peace and Development Initiatives (CPDI), College of Youth Activism and Development (CYAAD), Semoitics, Association of Global Humanists and Ethics (AGHE), Awaz- Center for Development Services (CDS), Governance Institutes Network International (GINI), Agency for Technical Cooperation and Development (ACTED), Nur Center for Research and Policy (NCRP). These were the 23 organizations associated with V\&A fund. There were 25 different grants awarded to these organizations. The table below gives a detailed analysis of the interventions made under this V\&A fund by virtue of these organizations.

Table 1. Details of projects/interventions under V\&A Fund

\begin{aligned} \hline SR \# & Organization \\ \hline 1. & $\begin{array}{l}\text { Democratic Commission for Human Development's } \\ \text { (DCHD) }\end{array}\end{aligned}$

2. Women's Welfare Organisation Poonch (WWOP)

3. Governance Institutes Network International (GINI)

4. Association of Global Humanists and Ethics' (AGHE)

5. Centre for Governance and Public Accountability's (CGPA)

6. Institute of Social and Policy Sciences' (I-SAPS)

7. Agency for Technical Cooperation and Development (ACTED)

8. Institute of Social and Policy Sciences (I-SAPS) (Special Grant)

9. Society for the Protection of the Rights of the Child (SPARC)

10. Consumer Rights Commission of Pakistan (CRCP)

\section{Project/ Intervention}

Worked with minority communities in Tehsil Chachro, Sindh to generate evidence on the reasons for low literacy levels and to improve government responses to lobbying efforts to enhance enrolment, accountability and better service delivery.

Worked with children with physical and learning disabilities in AJK and Punjab

Worked with children with physical and learning disabilities in AJK and Punjab, training of teachers and other officials and advocacy on inclusive education.

Targeted out-of-school girls in district Diamir, Gilgit Baltistan.

\section{District budget analysis}

Constituency Education Rankings

Development of high-quality primary research on children who had dropped out or were at risk of dropping out of school in Sindh.

Novel research on education procurement at the school, district and provincial level to promote the transparency and accountability of text book procurement, school construction and purchases by School Councils.

32 citizen advocacy groups engaged in meetings with district government officials in Multan and Bahawalpur to lobby for improvements in public school education services. Higher-level School Councils 
11. Centre for Governance and Public Accountability (CGPA)

12. Aga Khan University's Institute for Education Development (AKU-IED)

13. Trust for Democratic Education and Accountability/Free and Fair Election Network (TDEA/FAFEN)

14. Pakistan Coalition for Education (PCE) by SAQE

15. Farmers Development Organizations (FDO)

16. Express Publications

17. College of Youth Activism and Development (CYAAD)

18. Mishal

19. Centre for Peace and Development initiatives (CPDI)

20. Nur Centre for Research and Policy (NCRP)

21. Institute of Social and Policy Sciences (I-SAPS)

22. Semiotics

23. $\mathrm{CGN}$

24. LEAD Pakistan
Provincial and District Budget analysis for Improved Social Accountability

Comprehensive monitoring and evaluation process that included: (1) review of all project reports and products along with means of verification; (2) sample on-site verification; (3) data quality assessments (DQAs); and (4) rapid assessments and external evaluations.

Identify V\&A interventions in Pakistan which effectively engaged both demand and supply side mechanisms.

Building the capacity of state institutions and government officials; and promoting horizontal accountability.

Building capacity of local people to negotiate and lobby politicians and making their 'power of vote' conditional to highlight education issues

Content development on teacher recruitment and education budgeting.

University drives with students to promote the teaching profession.

community exhibitions showcasing social action projects

Journalists' directory

National Journalism Awards Ceremony awarding the best education reporters across the country

Participation in an education watch group inclusion of school health in the agenda of the Child Rights Movement

Ranking of political constituencies using an education scorecard indicating the status of education provision

Establishment of Education Planning Working Groups

Children's clubs

Engaged in a local research and advocacy campaign to increase access to evidence based knowledge on the state of education and community level involvement in it.

Other programmes included a weekly radio show 'Ilm i Pakistan - Kitabon se aagay' in collaboration with FM Power 99. The radio shows provided education sector experts, practitioners, activists, journalists and ilm ideas partners a platform to discuss key education challenges, and V\&A solutions by answering live calls.

An Education Policy Hub was held in August 2015 in Islamabad. The aim was to create an interface between public representatives and civil society actors to engage on key policy ask that emerged as a result of the voice and accountability fund. The Centre for Governance and Public Accountability (CGPA), the Consumer Rights Commission of Pakistan (CRCP) and the Institute of Social and Policy Sciences (ISAPS) were three grants that contributed the biggest share in the results. DFID also went for a third party evaluation of these grants. The third party evaluation for these three grants was conducted by Semiotics to attribute the share of results to each of these three grants. 
Table 2. Aid stopped by DFID for the projects

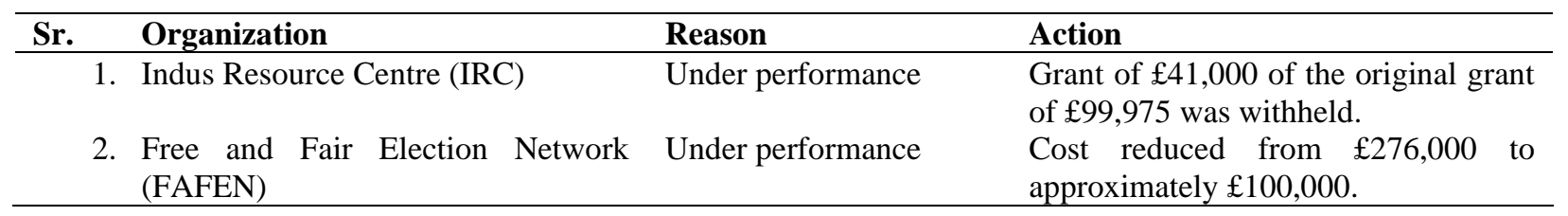

UK aid stops the payments of grants to the local-partners if they see that the progress is not satisfactory. They determine the progress of local-partners in the annual reviews. Based on the low satisfactory performance of these two grants were closed by UK aid in this fund.

\section{Innovative Fund for Education}

This fund started on November 25, 2011 and closed on October 31, 2015. There were 50 sub grants issued in this fund. Similar to voice and accountability fund this innovative fund for education was supported and managed by DAI. The total initial fund value of innovative fund was $£ 3$ million, but in April 2014 another $£ 3$ million were extended making it a $£ 6$ million fund.

\section{What specific interventions are introduced by $U K$ aid?}

The table below represents the grantees and their interventions for innovative fund for education.

Table 3. Grantees and their interventions for innovative fund for education

\begin{tabular}{|c|c|c|}
\hline SR \# & Organization/Grantee & Project/ Intervention \\
\hline 1. & The communicators & $\begin{array}{l}\text { 1. Broad Class - Listen to Learn } \\
\text { 2. Teacher training focused on interactive and } \\
\text { child-based methodology and using interactive } \\
\text { radio instruction (IRI) technology for an enabling } \\
\text { learning environment. }\end{array}$ \\
\hline 2. & Tele Taleem & Ilm on Wheels \\
\hline & & $\begin{array}{l}\text { Improvement in learning outcomes of students in } \\
\text { numeracy for grade } 2 \text { and mathematics for grade } 5 \text {. }\end{array}$ \\
\hline 3. & National Rural Support Program & Second shift schools for girls in boys' schools \\
\hline 4. & Idara e Taleem o Agahi (ITA) & $\begin{array}{l}\text { Established School capacity assessment tool and } \\
\text { rating system }\end{array}$ \\
\hline 5. & Bunyad Literacy Council & Targeted 7000 out of school children for enrolment \\
\hline 6. & Children's Global Network & $\begin{array}{l}\text { Skill for employability programme worked with } \\
900 \text { youth on entrepreneurship skills }\end{array}$ \\
\hline 7. & Management and Development Foundation (MDF) & 1. Improving quality of education \\
\hline & & 2. Teaching manual on participatory learning \\
\hline 8. & Punjab Directorate of staff development (DSD) & $\begin{array}{l}\text { Component of tele taleem adopted in teachers' } \\
\text { professional development }\end{array}$ \\
\hline 9. & Plan International & Corporal punishment redressal system \\
\hline 10 . & The Citizen Foundation (TCF) & Quality improvement programme \\
\hline 11. & $\begin{array}{l}\text { Institute for development and economic alternatives } \\
\text { (IDEAS) }\end{array}$ & Research study on public private partnership model \\
\hline 12. & Society for advancement of education (SAHE) & $\begin{array}{l}\text { 1. Research study on non-formal education models } \\
\text { 2. Use of pocket size projectors to deliver Khan } \\
\text { academy content in rural areas }\end{array}$ \\
\hline 13. & Family Education Services Foundation (FESF) & Sign language resources for deaf children \\
\hline 14. & Simorgh & Tri-lingual primers for early grades \\
\hline
\end{tabular}


15. Social Entrepreneurship Model (I-SEM)

16. CGN

17. Human Development Fund (HDF)

18. Socio-Engineering Consultants (SEC)

19. Trojan

20. Pakistan center for philanthropy
Developed a model to make grantees think and act like sustainable social businesses instead of development project only.

Training to youth on education entrepreneurship Digital study hall (DiSH) setting up TV screens in classroom to show educational content.

Active classroom initiative-interactive whiteboards

3D conceptual learning through computer aided design courses

Public private partnership for education

\section{Outcome of this innovative fund for education}

The outcome of this fund was "To increase access to quality education and to improve learning outcomes through innovative solutions" by engaging a wide range of organizations to develop and deliver solutions that can transform the education sector.

\section{Outcome targets}

Specifically, these were the outcome targets of innovative fund for education.

1. 20,000 additional children enrolled in schools as a result of innovative solutions (disaggregated by type, gender and level).

2. 50,000 students with improved learning achievements through innovative solutions (disaggregated by type, gender and level).

3. Ten innovative education solutions developed and tested that resulted in improved learning, access and/ or governance in the education sector.

In order to achieve these outcomes, following outputs were determined.

1. Increased access to quality education and improved learning outcomes through innovative solutions.

2. Development and articulation of innovative ideas for enhanced access, quality and/or governance.

3. Innovative solutions implemented for improved access, quality, satisfaction and/or governance in selected schools/districts.

\section{How are the recipients selected?}

Since this innovative fund for education was under the umbrella of Ilm Ideas programme, therefore, the international partner of DFID in this programme was the same as for education sector voice and accountability fund i.e. DAI. There is a contract signed between the government of the UK and the partner. The partner is referred as a fund manager or supplier. The key responsibilities of the fund manager are listed and agreed upon by the two parties in the contract. The contract details each and every procedure, timelines, terms of references, sub-grantees evaluation, monitoring and evaluation of the programme etc. in black and white. The main aim of this fund was to engage a wide range of organizations to develop and deliver solutions that can transform the education sector. To achieve this broader aim, innovative fund sought applications/ proposals on their RFAs. To ensure its success the team also considered a comprehensive outreach programme at district and sub-district level in order to identify a broad and diverse range of applications. 
The prime recipients of this fund were NGOS, CSOs, private organizations, and the secondary recipients include government of Pakistan and international development organizations. But DFID has tried to be in close liaison with the government right from the start of the programmes to ensure durability and effectiveness. The fund manager, DAI in this programme was responsible to invite, short list, select, grant, monitor, and evaluate the sub-grantees through RFA. The proposals are received and then vetted through administrative review, technical review, and due diligence. There were 36 organizations who were awarded 50 funds.

Both the funds, in post-implementation stage, selected by the researcher were running under Ilm ideas programme. Therefore, most of the procedures and processes were similar in the two funds. Through the annual review reports the researcher has concluded that these two funds were successful in terms of achieving their objectives. This is ascertained by the rating the annual reviews have given in evaluations. In some of the years during the programme duration the two funds even over performed than the set targets. But these are the findings from the document analysis of the UK aid review reports, in order to evaluate this programme from the recipients' perspective and interest, the educational outcomes and indicators were also reviewed, analyzed and compared with the findings given above. This analysis has been expressed in the discussion section below.

\section{Discussion}

Research question 1. What were the objectives of the two funds voice and accountability and innovative fund for education?

For both the funds three outcomes were planned. In order to achieve those outcomes, specific output targets are set. These have been explained above in the document analysis section of this paper. These targets and outcomes were planned in accordance with the gaps in the education sector of Pakistan. The funds were initiated after adequate need assessment procedures and could prove really helpful to the education system of Pakistan. UK aid does the need assessment before initiating any programme and the feasibility is comprehensively explained in the business case document of UK aid for every programme. UK aid has always specific objectives for a programme, and this specialization helps in addressing the identified problems. Abdullah and Akhtar (2019) evaluated another programme of the UK aid in Pakistan and found out that in a programme, UK aid pursue the objectives with rigour and continuous internal monitoring.

Research question 2. What interventions were introduced to achieve those objectives?

There have been numerous interventions planned and initiated under these two funds. The voice and accountability fund had 25 grants issued in different interventions while innovative fund for education was given 50 grants to introduce interventions. The details of each grantee and their interventions have been explained in detail above for voice and accountability (see Table 1) for innovative fund for education (see Table 3). Worth mentioning is that the funds for two sub grants had been stopped by UK aid under voice and accountability fund. This highlights the significant role of monitoring and evaluation of UK aid as it had stopped the funds based on their own annual review reports. There was a continuous mechanism of monitoring at many fronts for the interventions. Firstly, the grantee(s) itself did internal monitoring and evaluation of the activities, secondly, the fund partner did the monitoring of funds utilization, DFID also managed a regular monitoring framework, moreover, DFID had allocated separate fund within this programme specifically for monitoring purpose. Thirdly, an independent third party annual review was conducted by DFID for target assessment, value for money, commercial consideration, and efficiency and effectiveness. Lastly, the government departments involved with these funds such as Government of the Punjab also monitored the progress through its departments and a reform programme, Chief Minister School Education Reform Roadmap (School Education Department, 2016) was also looking after and working on 
similar targets. Therefore, based on the strict monitoring checks it might be safely said that the interventions were executed as planned and the sub grantees achieved their planned changes. (Robertson, 2005) concluded that interventions should align with the objectives as the success of any program depends upon its planned interventions. The impact of these interventions and success in achieving the targets is discussed in the questions below.

Research question 3. How far were those objectives met?

The objectives of the programme were likely met as per the annual reviews of DFID. Although these reviews are third party reviews yet the researcher in this paper has not relied on the reviews only. The reviews have given a ranking of ' $\mathrm{A}$ ' for the two programmes and in some of the years even A+ was awarded which is interpreted as exceeding the targets. However, the researcher has compared the educational outcomes and indicators with the objectives of the two funds. This comparison has added to the contextual understanding of educational realities and problems of Pakistan. For instance, the objective of enhancing education budget allocation to 4\% of GDP has not been achieved by this programme. The latest official governmental figures are 2.1\% of GDP (Government of Pakistan, Finance Division, 2017-18). It is quite low as compared to the neighbouring countries in the region. In 2011, when this programme was initiated the GDP allocation was $1.91 \%$ and in 2015 when its duration completed the GDP was $2.10 \%$. The education budget, GDP and their percentage for the year 2011 to 2015 is given in the table below.

Table 4. Education to GDP values and percentages (2011-2015)

\begin{tabular}{llll}
\hline Year & Education (Rupees in Million) & GDP (Rupees in Billion) & Percentage \\
\hline 2011 & 40324 & 21041 & 1.91 \\
2012 & 45214 & 23655 & 1.91 \\
2013 & 52371 & 26001 & 2.01 \\
2014 & 63442 & 29078 & 2.18 \\
2015 & 64519 & 30672 & 2.10 \\
\hline
\end{tabular}

Source: Finance division, Government of Pakistan, budget briefs (2011-12 to 2015-16)

Although the table above gives an incremental trend in the percentage of education to GDP but there are two things that help decipher this increase (a) the increase is not up to $4 \%$ and (b) this increase cannot be solely attributed to the programme. There is no such evidence that this increase in the years is because of ilm ideas alone. However, since this was a limitation of this research that it did not account for the other reasons that lead to the increase in the education budget, it may be said that consistent efforts of UK aid started reaping results, how trivial they might be.

Abbas and Ahmed (2014) analyzed the social accountability and service delivery in Pakistan and pointed out many challenges especially in the education sector. They suggested continuous and persistent efforts in accountability practices in education, particularly through the establishment and encouragement of CSOs. As far as the objectives related to the education indicators such as increased enrollment of students and learning outcomes are concerned the following table sums up the progress towards them. The table represented Gross Enrollment Rate (GER) (6 to 10 years), Net Enrollment Rate (NER) (6 to 10 years), Gender Parity Index (GPI) for primary and secondary classes for the years this programme was functional in Pakistan. With persistent efforts Pakistan has been able to maintain its key indicators in spite of the increase in population and school age children every year.

Table 5. Year wise comparison of key education indicators of Pakistan

\begin{tabular}{lllll}
\hline Year & GER (6 to 10 years) & NER (6 to 10 years) & GPI (primary) & GPI (secondary) \\
\hline $2011-12$ & 92 & 68 & 0.90 & 0.81 \\
\hline
\end{tabular}




\begin{tabular}{lllll}
\hline $2012-13$ & 92 & 68 & 0.89 & 0.89 \\
$2013-14$ & 91 & 65 & 0.88 & 0.84 \\
$2014-15$ & 91 & 67 & 0.88 & .087 \\
\hline
\end{tabular}

Source: PSLM Data of Pakistan Bureau of Statistics for the years (2011-12 to 2014-15)

Research question 4. What changes in the educational outcomes this programme has brought?

Pakistan is still behind its own set targets and achievements, nevertheless, as a result of this programme, it has started making progress. Regarding the innovative solutions and policy documentation objectives of the ilm ideas, much effort have been made, and a policy draft is almost ready. Although the process of new educational policy has seen some delay because of the General Elections of 2018 in Pakistan and the change in the elected governments at federation and provinces, yet the draft promises some innovations especially at school education level. Pakistan has participated in the TIMSS in the year 2019 for grade $4^{\text {th }}$ only (NCES, 2020) and also planning to take part in the upcoming PISA (NEAS, 2019). This will certainly help determine the learning capabilities of students and further policy work can be done and gaps in the learning and quality may be identified. These two international large scale assessment tests might help Pakistan in assessing its students' achievements and altogether rethink about its learning outcomes.

According to Cornell University, INSEAD and WIPO (2018) in global innovation index report of 2018 Pakistan is ranked 109 out of 126 participating countries. This also highlights the innovative ideas and solution situation in Pakistan, which has not improved significantly. There are many similar programmes by DFID that cater and address other aligned deficiencies of the education system of Pakistan (DFID Projects in Pakistan, 2016). The government of Pakistan is also keen to improve its education quality. Other indicators such as teacher-pupil ratio, infrastructure, missing facilities in public schools, teacher qualifications and trainings, students' retention, survival, and transition rates are addressed on priority in some of the other reform programmes by DFID. One criticism on UK aid by Curtis (2015) in aid evaluation is that it supports private sector a bit too much. As is evident in this programme, most grantees belonged to the private sector. Government of Pakistan has to see its priority and set that in educational policy and framework about the role of private sector in education. Running parallel forms of schools might not be favourable for Pakistan.

In this way, the answers to the subsidiary research questions were provided with discussion embedded in the education indicators and outcomes, and context specific dynamics, hence, addressing the main question of the study that was to find the benefits of the programme ilm ideas in terms of the change it has brought to the education indicators of Pakistan.

\section{Conclusion and Recommendations}

Ilm ideas was a national level programme and it focused on increasing public demand for quality of education and innovative ideas for enhancing learning outcomes of students. Private sector was involved specially, NGOs and CSOs, in introducing interventions. Sum of the targets that were related to the awareness were achieved and a few substantial targets such as increasing educational budget up to $4 \%$ of GDP, and other education indicators still needs improvements and efforts. These problems are associated with the budgetary deficit that compliance with the economic activities in the countries. Therefore, it is concluded that a comprehensive economic and social reform programme is needed at the moment for Pakistan. All segments of the society, especially private sector have a role to play in achieving quality education.

Ilm ideas programme was successful and based on its results; UK aid has continued this programme in phase II. Ilm Ideas-II was functional in Pakistan (2019), which shows the commitment of UK aid to the 
education system of Pakistan. The phase II has attended the out of school children issue in Pakistan. It is recommended that similar evaluations of the aided programmes is needed by the Pakistani education system and think tank in order to make better strategy and to do need assessment. Such evaluations will determine the role of foreign aid agencies in the education system; moreover, it may highlight the gaps and possible improvement opportunities for the donors as well as the recipients. However, in further evaluation research, the researchers might like to see an evaluation of the grantees and their interventions. It will be a large scale research study, however it will address the impact and ground realities of operations and functions of grantees that were a few identified limitations of the present research.

\section{References}

Abbas, M. H., \& Ahmed, V. (2014). Challenges to social accountability and service delivery in Pakistan. The Sustainable Development Policy Institute. Retrieved from: https://www.sdpi.org/publications/files/Challenges\%20to\%20Social\%20Accountability\%20And \%20Service\%20Delivery\%20in\%20Pakistan\%20(W145).pdf

Academy of Educational Planning and Management (2018). Educational policies and plans of Pakistan. Ministry of Federal Education and Professional Training. Government of Pakistan. Retrieved from: http://library.aepam.edu.pk/

Angers, J., \& Machtmes, K. (2005). An ethnographic-case study of beliefs, context factors, and practices of teachers integrating technology. The Qualitative Report, 10(4), 771-794.

Asim, M., \& Shah, S. R. A. (2014). Educational System in British India and its Socio-Political Impacts on Pakistani Society. International Journal of Innovation and Applied Studies, 7(1), 87-97.

Bengali, K. (1999). History of Education policy making and planning in Pakistan. Sustainable policy development Institution. Working paper series no. 40.

Bowen, G. A. (2009). Document analysis as a qualitative research method. Qualitative Research Journal, 9(2), 27-40.

Braun, V., \& Clarke, V. (2006). Using thematic analysis in psychology. Qualitative Research in Psychology, 3(2), 77-101.

Chen, H. T. (2005). Practical programme evaluation: Assessing and improving planning, implementation, and effectiveness. Thousand Oaks, CA: Sage.

Corbin, J., \& Strauss, A. (2008). Basics of qualitative research: Techniques and procedures for developing grounded theory ( $3^{\text {rd }}$ ed.). Thousand Oaks, CA: Sage.

Cornell University, INSEAD \& WIPO (2018). The global innovation index report 2018. Retrieved from: file:///Y:/Download\%20Chrome/GII\%202018\%20Full\%20print.WEB.pdf

Curtis, M. (2015). DFID's controversial support for private education. Curtis research independent development policy analysis. Retrieved from http://curtisresearch.org/wp-content/uploads/ReportDFID-Education-Curtis-September-2015.pdf

Development Tracker (2016). Top 5 places UK AID work. Retrieved from the official website of UK AID development track. https://devtracker.dfid.gov.uk 
DFID (2018). DFID Pakistan. Planned Budget. Retrieved online from: https://assets.publishing.service.gov.uk/government/uploads/system/uploads/attachment data/file/ 636548/Pakistan1.pdf

DFID Operational Plan (2014). Operational plan 2011-16. DFID Pakistan. Retrieved from: https://assets.publishing.service.gov.uk/government/uploads/system/uploads/attachment data/file/ $\underline{389059 / \text { Pakistan.pdf }}$

DFID Projects in Pakistan (2016). List of the programmes under DFID currently functional in Pakistan. Available online at: http://www.developmentadvisor. pk/role-of-donors-in-pakistandevelopment/dfid/dfid-projects-in-pakistan/.

Government of Pakistan, Ministry of Finance (2018). PRSP Budgetary Expenditures, External Finance Policy Wings, Finance Division, Islamabad. [Data file]. Retrieved from http://www.finance.gov.pk/poverty/PRSP_Expenditure FY_2017_18_Q2.pdf.

Government of Pakistan, Finance Division. (2017-18). Economic Survey of Pakistan 2017-18. Retrieved from http://www.finance.gov.pk/survey/chapters 18/10-Education.pdf

NCES (2020). TIMSS participating countries. Institute of Education Sciences (IES): TIMSS USA. Retrieved from: https://nces.ed.gov/timss/countries.asp

NEAS (2019). Pakistan's participation in Trends in International Math and Science Study; TIMSS-2019. Retrieved from: http://www.neas.gov.pk/Calander\%20of\%20Activities.html

Padilla-Diaz, M. (2015). Phenomenology in educational qualitative research: Philosophy as science or philosophical science. International Journal of Education Excellence, 1(2), 101-110.

Pakistan Bureau of Statistics (2017). District wise census results census 2017. $6^{\text {th }}$ population and housing census-2017. Retrieved from: http://www.pbs.gov.pk/content/provisional-summary-results-6thpopulation-and-housing-census-2017-0

Pakistan Bureau of Statistics (2016). Pakistan Social and Living Standards Measurement Survey (201415). Government of Pakistan. Islamabad. Retrieved from: http://www.pbs.gov.pk/sites/default/files/ps/m/publications/PSLM_2014-15_National-ProvincialDistrict_report.pdf

Pakistan Education Statistics (2016-17). Out of school children in Pakistan by levels. National Education Management Information System. Academy of Educational Planning and Management. Ministry of Federal Education and Professional Training. Government of Pakistan. Islamabad. Available at: http://library.aepam.edu.pk/Books/Pakistan\%20Education\%20 Statistics\%202016-17.pdf

Robertson, S. L. (2005). Re-imagining and rescripting the future of education: Global knowledge economy discourses and the challenge to education systems, Comparative Education, 41(2), 151-170. DOI: 10.1080/03050060500150922

Sarwar, A., Hassan, M., \& Mahmood, T. (2015). Foreign aid and governance in Pakistan. Pakistan Economic and Social Review, 53(2), 149-176.

School Education Department (2016). CM school reform roadmap. Retrieved from: https://schools.punjab.gov.pk/schoolroadmap 
Steiner-Khamsi, G. (2006). The economics of policy borrowing and lending: A study of late adopters. Oxford Review of Education, 32(5), 665-678.

Yin, R. K. (2011). Qualitative research from start to finish. New York, NY: Guilford.

Yin, R. K. (2009). Case study research: Design and methods, (4 ${ }^{\text {th }}$ ed.). Thousand Oaks: Sage. 